\title{
Sprawozdanie z II Ogólnopolskiej Konferencji Parentologicznej "Rodzicielstwo w zmieniającym się świecie”, 15-16.06.2021 r.
}

W dniach 15-16.06.2021 roku odbyła się II Ogólnopolska Konferencja Parentologiczna, która oscylowała wokół zakresu tematycznego dotyczącego rodzicielstwa w zmieniającym się świecie. Konferencję zorganizował Wydział Psychologii i Kognitywistyki Uniwersytetu im. Adama Mickiewicza w Poznaniu. Ze względu na panującą w kraju sytuację epidemiologiczną została ona zainicjowana w formule zdalnej, a zatem kontakt odbywał się za pośrednictwem urządzeń elektronicznych.

Konferencja podzielona została na 15 sesji referatowych, w tym jedna z nich przyjęła formę sesji plakatowej. Każdy z dwóch dni obrad zaczynał się wygłoszeniem jednego wykładu plenarnego. Prelegentkami były: prof. UG dr hab. Maria Kaźmierczak oraz dr hab. Katarzyna Kabacińska-Łuczak. Na całokształt konferencji złożyło się 66 wystąpień oraz dwa, wspomniane wyżej, wykłady plenarne. Sesje obfitowały w liczne dyskusje związane $\mathrm{z}$ analizami różnorodnych doświadczeń rodzicielstwa w zmieniającym się świecie.

Każda z piętnastu sesji obejmowała inny zakres tematyczny, który stanowił motyw przewodni referatów wygłaszanych podczas konferencji. Tematy sesji referatowych w pierwszym dniu obrad, tj. 15 czerwca 2021 roku to: doświadczenia rodzicielskie; prawne aspekty rodzicielstwa; rodzicielstwo osób LGBTQ+ i rodzicielstwo wobec dzieci LGBTQ+; matki i ojcowie w zmieniającej się rzeczywistości; rodzicielstwo wobec współczesnych wyzwań; podejmowanie i gotowość do ról rodzicielskich; doświadczenia rodziców na różnych etapach życia; rodzice a edukacja. W drugim dniu obrad konferencyjnych (16 czerwca 2021 roku) zajęto się z kolei następującymi zagadnieniami: rodzicielstwo w obliczu trudności, cz. 1 oraz cz. 2; pandemia COVID-19 w doświadczeniach matek; sesja plakatowa; pandemia COVID-19 w doświadczeniach rodziców. Ostatnią sesją była sesja studencka, która obejmowała cztery wystąpienia studentów i studentek z Uniwersytetu im. Adama Mickiewicza w Poznaniu oraz Uniwersytetu Mikołaja Kopernika w Toruniu.

Obrady zostały zainicjowane przez pana Dziekana Wydziału Psychologii i Kognitywistyki Uniwersytetu im. Adama Mickiewicza w Poznaniu, prof. UAM dr. hab. Mariusza Urbańskiego, który powitał wszystkich prelegentów oraz przybyłych gości. W dalszej części głos zabrała przewodnicząca Komitetu Naukowego oraz Organizacyjnego pani prof. UAM dr hab. Lucyna Bakiera, która oficjalnie 
otworzyła konferencję oraz przybliżyła jej zakres tematyczny, odwołując się do podstaw teoretycznych zagadnień stanowiących oś analiz, a także przedstawiła porządek obrad.

Po oficjalnym rozpoczęciu konferencji oraz przywitaniu wszystkich gości głos został oddany pierwszej prelegentce, mianowicie pani prof. Uniwersytetu Gdańskiego dr hab. Marii Kaźmierczak, która wygłosiła pierwszy z dwóch wykładów plenarnych pt. „Ojcostwo w rozwoju - dynamika procesu podejmowania ról rodzicielskich". Pani profesor Maria Kaźmierczak zaprezentowała analizy procesu podejmowania ról rodzicielskich, podkreślając jednocześnie wieloaspektowość roli ojca. Na podstawie aktualnej literatury psychologicznej oraz badań własnych dokonała także analizy czynników indywidualnych oraz interpersonalnych, które wpływają na proces kształtowania tej roli.

Po zakończeniu pierwszego wykładu plenarnego pani profesor Lucyna Bakiera zaprosiła wszystkich do uczestnictwa w poszczególnych sesjach tematycznych. W tym miejscu zakończone zostały obrady na kanale głównym konferencji oraz nastąpiło przejście do kanałów tematycznych.

Pierwsza sesja oscylowała wokół doświadczeń rodzicielskich i kolejno głos zabrały: pani prof. KUL dr hab. Bogusława Lachowska oraz pani mgr Sabina Więsyk, które zaprezentowały wystąpienie pt. „Współpraca rodzicielska - wyniki wstępnych analiz na gruncie polskim”. Prelegentki omówiły zagadnienia dotyczące koncepcji współpracy rodzicielskiej autorstwa Marka Feinberga oraz wstępnych analiz polskiej wersji skali Współpracy Rodzicielskiej. Kolejnymi prelegentkami były: pani prof. dr hab. Marta Białecka-Pikul, pani dr Małgorzata Stępień-Nycz oraz pani mgr Martyna Jackiewicz-Kawka. Referat, który został wygłoszony przez prelegentki, nosił tytuł: „Styl rodzicielski czy styl matki i styl ojca? Spójność stylów rodzicielskich par rodziców z punktu widzenia obojga partnerów”. Prelegentki w przygotowanym wystąpieniu przedstawiły wyniki badań dotyczące stylów rodzicielskich, otrzymane na postawie analiz odpowiedzi wybranej grupy rodziców. W dalszej kolejności oddano głos pani dr Dorocie Szczygieł, która zaprezentowała referat pt. „Kulturowe uwarunkowania wypalenia rodzicielskiego", czyli doświadczenia wpisanego w rodzicielstwo wielu osób. Przedostatni referat wygłosiła pani mgr Beata Granops, której wystąpienie nosiło tytuł: „W poszukiwaniu »intersubiektywności« w relacji rodzic - niemowlę - refleksja nad koncepcją Colwyna Trevathena na podstawie metody Obserwacji Niemowląt Esther Bick". Jako ostatnia w tej części swój referat zaprezentowała pani mgr Monika Kiszka, która przedstawiła rozważania dotyczące realizowania macierzyństwa zastępczego w postaci podejmowania roli matki w SOS Wioskach Dziecięcych. Autorka swoje wystąpienie oparła na teoretycznej syntezie literatury przedmiotu, która pozwoliła na wyłonienie formalnych podstaw pełnienia „zawodu” matki w SOS Wioskach Dziecięcych. Tym referatem zakończyła się pierwsza sesja plenarna, po której nastąpiła przerwa przed rozpoczęciem kolejnej części wystąpień.

Drugą sesję rozpoczęło wystąpienie pt. „Kontakty z dzieckiem po rozwodzie”, wygłoszone przez panią dr Joannę Zajączkowską-Burtowy, która zwróciła uwagę, że ten temat jest jednym z najczęściej poruszanych, gdy jest mowa o relacjach pomiędzy rodzicami a dzieckiem. Kolejna prelegentka zajęła się tematem związanym $\mathrm{z}$ alienacją rodzicielską $\mathrm{w}$ aspekcie psychologicznym i prawnym. Pani dr Anna Wilk przybliżyła kwestie związane z utrudnianiem kontaktów dziecku z jednym rodzicem na skutek działań drugiego rodzica. W dalszej kolejności wystąpienie wygłosił pan mgr Marceli Kwaśniewski, który zajął się mediacją, konfliktem rodzicielskim oraz alienacją. Prelegent przybliżył aspekty związane z mediacją jako metodą możliwego wsparcia skonfliktowanych rodziców, tak aby mogli oni podjąć odpowiednie czynności w celu prawidłowego wypełniania swojej roli rodzicielskiej. Kolejnym prelegentem był pan mgr Dariusz Szenkowski, który analizował wartość dowodu z opinii psychologicznej biegłego sądowego lub OZSS w postępowaniu przed sądem rodzinnym. W tytule zawarte zostało też pytanie: Czy polskie prawo chroni rodzicielstwo w sytuacji rozpadu rodziny? Ostat- 
nie z wystąpień w drugiej sesji odnosiło się do praktyki rozpowszechniania wizerunku małoletniego w sieci (na styku granic władzy rodzicielskiej i autonomii dziecka). Pani mgr Adriana Denys-Starzec poszukiwała odpowiedzi na pytanie dotyczące wielokrotnego oraz nadmiernego rozpowszechniania wizerunku dziecka, które może zostać uznane za zgodę upubliczniania wizerunku przez dziecko.

Trzecia sesja obejmowała tematy związane z rodzicielstwem osób LGBTQ+ i rodzicielstwem wobec dzieci LGBTQ+. Pierwsze z wystąpień zaprezentowane zostało przez panią dr hab. Danutę Urygę i nosiło tytuł: „Jesteś moim dzieckiem, nie ideologią” - aktywistyczne praktyki normalizacyjne rodziców osób LGBTQIA". Kolejna prelegentka - pani dr Katarzyna Gajek - podjęła temat związany z rodzicielską aktywnością na rzecz społeczności LGBTQIA na przykładzie mediów społecznościowych. Celem wystąpienia było dokonanie rekonstrukcji aktywności na rzecz społeczności LGBTQIA. W dalszej kolejności głos zabrała pani dr Agnieszka Kwiecień-Madej, która zaprezentowała wybrane aspekty prawne rodzicielstwa osób transseksualnych. Kolejny prelegent - pan dr Andrzej Margasiński - poruszył zagadnienia związane z rodzicielstwem par homoseksualnych (trudności metodologiczne i przegląd badań). Wystąpieniem zamykającym trzecią sesję był referat pani mgr Agnieszki Marianowicz-Szczygieł, która zajęła się tematem eksplozji zaburzeń tożsamości płci wśród dzieci i młodzieży i związanych z tym dylematów rodziców.

„Matki i ojcowie w zmieniającej się rzeczywistości” to motyw przewodni czwartej sesji referatowej w ramach obrad konferencyjnych. Pierwsze wystąpienie dotyczyło pożegnania z patriarchatem i obejmowało refleksję dotyczącą najważniejszych uwarunkowań przemian roli ojca w rodzinie w XIX oraz XX wieku. Pan dr Mikołaj Gębka poszukiwał cech, które można uznać za charakteryzujące tożsamość roli ojca oraz ewentualnych postępujących zmian w postrzeganiu tradycyjnej roli ojca w rodzinie. W dalszej kolejności swoje wystąpienie wygłosili: pani dr Iwona Sikorska, pan dr Mateusz Polak oraz pani mgr Magdalena Adamczyk-Banach. Prelegenci poszukiwali odpowiedzi na pytanie odnoszące się do związku pomiędzy odpornością psychiczną rodziców a odpornością psychiczną dzieci. Natomiast pani dr Anna Szklarska zajęła się tematem związanym z problemem pierwszeństwa. Kluczowym zagadnieniem stało się pytanie: o które dzieci jesteśmy zobowiązani się troszczyć? Autorka omówiła problem związany z pierwszeństwem własnych dzieci nad dobrem innych dzieci, z którymi jesteśmy związani poprzez stosunek pracy czy opieki. Kolejną prelegentką była pani dr Magdalena Witkowska, która zajęła się postawami rodzicielskimi sprzyjającymi wielodzietności. Autorka wskazała na rezultaty badań, które obejmowały uwarunkowania funkcji prokreacyjnej w rodzinach wielodzietnych. Wystąpieniem zamykającym czwartą sesję był referat pani lic. Aleksandry Kaczyńskiej, która podjęła temat klapsa za karę. Analizie poddane zostały postawy rodziców wobec stosowania kar fizycznych w wychowaniu dziecka.

Piąta sesja obejmowała tematy związane z rodzicielstwem w dobie współczesnych wyzwań. Pierwsze wystąpienie zostało wygłoszone przez panią prof. UAM dr hab. Ewę Włodarczyk, która zajęła się tematem punktów zwrotnych na kontinuum od uzależnienia do zdrowienia w pamięci autobiograficznej matek uzależnionych od alkoholu. W dalszej kolejności głos zabrała pani dr Katarzyna Góra, która zajęła się konceptualizacją rodzicielstwa w ujęciu kognitywnym. Prelegentka ukazała analizę różnorodnych metafor, które obejmowały rodzicielstwo opisywane w literaturze. Przeprowadzona analiza może dostarczyć narzędzi pozwalających pogłębić wiedzę dotyczącą macierzyństwa oraz parentologii. Następnie pani dr Olga Zamecka-Zalas wygłosiła referat pt. „Rola rodziców w wychowaniu ojczystym na przykładzie ich współpracy ze szkołami przedmiotów ojczystych w Londynie". W dalszej kolejności pani mgr Katarzyna Tarłowska poświęciła uwagę zagadnieniom dobrych praktyk na rzecz wspierania rodziców na przykładzie działalności Klubu Dobrych Rodziców w Centrum Wspierania Rodzin „Swoboda” w Poznaniu. Wystąpienie oscylowało wokół 
prezentacji działalności Klubu Dobrych Rodziców. Ostatnim wystąpieniem w sesji piątej był referat wygłoszony przez panią mgr Annę Murawską, która zajęła się wpływem działalności Akademii Familijnej oraz amatorskiego Teatru Biedronka na kształtowanie się postaw rodzicielskich w zakresie decyzji prokreacyjnych.

Sesja szósta obejmowała referaty dotyczące tematyki podejmowania oraz gotowości do ról rodzicielskich. W pierwszej kolejności głos zabrała pani dr hab. Dorota Ruszkiewicz, która podjęła rozważania dotyczące rodzicielstwa rodziców chrzestnych. Następnie pani dr Karolina Appelt oraz pani Iga Grzywaczewska analizowały problem psychospołecznej dojrzałości młodych mężczyzn i ich gotowości do ojcostwa w kontekście korzystania z gier komputerowych. Pani dr Anna Szymanik-Kostrzewska oraz pani dr Paulina Michalska skupiły się na temacie: „Rozwiązywanie problemów związanych z macierzyństwem w kontekście rozumowania postformalnego - dobro dziecka a dobro matki w opiniach matek, ojców, młodych dorosłych nieposiadających dzieci oraz seniorów obu płci”. Referat miał na celu przedstawienie wyników badań, które przeprowadzone zostały z wykorzystaniem autorskiego narzędzia - Kwestionariusza „Rady dla Matek”. Przedostatnie wystąpienie w szóstej sesji referatowej dotyczyło muzykoterapii jako formy wsparcia dla dziecka i rodzica na oddziale neonatologii. Pani dr Sara Knapik-Szweda przedstawiła zastosowanie muzykoterapii i jej korzystny wpływ na dzieci przebywające po urodzeniu na oddziale intensywnej terapii. W dalszej kolejności pani prof. UAM dr hab. Lucyna Bakiera oraz pan Paweł Ciesielski przedstawili rozważania dotyczące nastawienia rodzicielskiego młodych dorosłych w kontekstach rozwoju psychospołecznego.

Siódma sesja oscylowała wokół tematów związanych z doświadczeniami rodziców na różnych etapach życia. Pani prof. APS dr hab. Ewa Zasępa zaprezentowała referat dotyczący Kwestionariusza Doświadczeń Rodzicielskich jako propozycji narzędzia badawczego. W dalszej kolejności głos zabrała pani prof. dr hab. Maria Sroczyńska, która przedstawiła referat dotyczący wizerunku rodziców w percepcji młodych u progu dorosłości w perspektywie badań panelowych. Kolejne wystąpienie odnosiło się do tematu intymności i okazywania bliskości rodziców wobec siebie i zostało przedstawione przez panią prof. UAM dr hab. Lucynę Bakierę oraz panią dr Izabelę Stankowską-Mazur. Następna prelegentka - pani dr Małgorzata Weryszko - swoje rozważania skoncentrowała na zagadnieniu związanym z jakością małżeństwa a stylem pełnienia roli ojca. Wystąpieniem zamykającym obrady tej sesji był referat pani dr Magdaleny Żadkowskiej oraz pani mgr Magdaleny Herzberg-Kurasz, które zaprezentowały analizy dotyczące problematyki pustoszejącego gniazda, ukazując (nie)zmienną rolę matki. Prelegentki skoncentrowały się na zmianach następujących w życiu matki, której dzieci opuszczają dom rodzinny.

„Rodzicielstwo wobec współczesnych wyzwań” to motyw przewodni kolejnej - ósmej - sesji. Pierwszy referat, zaprezentowany przez panią prof. UAM dr hab. Aleksandrę Parobkiewicz-Jasielską oraz pana mgr. Kamila Janowicza dotyczył komercjalizacji tacierzyństwa, czyli ojców jako adresatów działań marketingowych. W dalszej kolejności pani dr Dominika Myślak wygłosiła referat pt. „Rodzicielstwo w Sieci - wizja, rzeczywistość, perspektywy”. Analizie poddane zostało rodzicielstwo, które coraz częściej staje się tematem wyszukiwania w Internecie. „Macierzyństwo w labiryntach codzienności. Trudności - wyzwania - priorytety współczesnego macierzyństwa” stanowiły kolejny aspekt poddany analizie, przeprowadzonej przez panią dr Monikę Lewicką. W wyżej wymienionym referacie macierzyństwo zostało ujęte w kontekście zmian zachodzących we współczesnej rzeczywistości. Następnie pani mgr Maja Chojnacka oraz pani mgr Patrycja Michalak-Wachowiak przedstawiły referat dotyczący rodzicielstwa zastępczego, analizując jego szanse oraz trudności. Ponadto prelegentki dokonały opisu specyfiki funkcjonowania rodziny zastępczej. Wyróżnione zostały rozmaite koncepcje odnoszące się do doświadczeń dzieci oraz rodziców adopcyjnych. „Rok przed wdro- 
żeniem dyrektywy UE work-life balance - percepcja rozwiązania prawnego w kontekście ewolucji ról rodzicielskich" to ostatni referat w sesji ósmej, wygłoszony przez panią dr Martę Biercę.

W kolejnej sesji zajęto się kwestią: „Rodzice a edukacja”. Pierwszy z czterech referatów dotyczył relacji z matką jako predyktora sukcesów szkolnych młodzieży. Prelegentką była pani prof. UJD dr hab. Elżbieta Napora. Zaprezentowane zostały wyniki badań własnych, podczas których poszukiwano odpowiedzi na pytanie, czy rodzaj oraz charakter relacji z matką mogą stać się głównym wyznacznikiem sukcesów edukacyjnych. Drugie wystąpienie zaprezentowane zostało przez panią dr Beatę Adrjan, która dokonała analizy zebranych danych z badań dotyczących miejsca rodziców w szkole. Prelegentka na podstawie konkluzji treści nagrań zebrań w klasach I-III dokonała rekonstrukcji pozycji rodziców w trakcie zebrań w szkole. W dalszej kolejności moderator sesji referatowej oddał głos pani dr Bogumile Bobik, która wygłosiła referat pt. „Współpraca rodziców i szkoły w czasie edukacji zdalnej". Wystąpieniem zamykającym sesję dziewiątą był referat pani lic. Wiktorii Olszewskiej, która zajęła się tematem edukacji seksualnej w oczach rodziny osób z niepełnosprawnością intelektualną. Prelegentka podjęła się analizy kwestii edukacji seksualnej, która uważana jest za temat tabu, wywołujący skrajne emocje.

Powyższym wystąpieniem zakończył się pierwszy dzień konferencji. Podkreślić należy, iż obfitował on w znaczną liczbę wystąpień oraz dyskusji, które pozwoliły na wyłonienie wniosków służących lepszemu zrozumieniu rodzicielstwa w aspekcie zmieniającego się świata.

Drugi dzień obrad rozpoczął wykład plenarny pani dr hab. Katarzyny Kabacińskiej-Łuczak z Zakładu Historii Wychowania Wydziału Studiów Edukacyjnych Uniwersytetu im. Adama Mickiewicza w Poznaniu pt. „(Nie)zmienne rodzicielstwo - o funkcjach rodziny na ziemiach polskich do końca XIX wieku”. Podczas wystąpienia poruszone zostały kwestie (nie)zmienności funkcji, które sprawowane są przez rodzinę (funkcji wychowawczej, opiekuńczej, ekonomicznej oraz prokreacyjnej). Ponadto przytoczone zostały cechy, które charakteryzowały rodzinę dawniej. Analizie poddane zostały także pozycje członków rodziny. Po wygłoszonym wykładzie wszyscy prelegenci oraz obecni goście zostali zaproszeni do dołączenia do odpowiednich, zaplanowanych w tym dniu, sesji tematycznych.

Sesja dziesiąta dotyczyła tematu związanego z rodzicielstwem w obliczu trudności. Pierwszą prelegentką była pani prof. UJD dr hab. Elżbieta Napora, która omówiła zagadnienia dotyczące samotnego macierzyństwa oraz znaczenia dziadków dla relacji adolescentów z rówieśnikami. Pani dr Krystyna Moczia zajęła się natomiast tematem postaw rodzicielskich rodziców dzieci ze zdiagnozowaną niskorosłością. Prelegentka zaprezentowała analizy odnoszące się do badań własnych, które przeprowadzone zostały z wykorzystaniem metody sondażu diagnostycznego. W dalszej kolejności głos został oddany pani dr hab. Grażynie Kmicie oraz pani mgr Justynie Cieślińskiej, które wygłosiły referat pt. „Doświadczenie ojcostwa w sytuacji narodzin dziecka zagrożonego niepełnosprawnością - analiza narracyjna”. Prelegentki dokonały pogłębienia wiedzy związanej z postrzeganiem przez ojców sytuacji urodzenia dziecka zagrożonego niepełnosprawnością. Wystąpienie zamykające tę sesję dotyczyło z kolei doświadczeń macierzyństwa w trakcie choroby nowotworowej. Pani mgr Joanna Matuszczak-Świgoń przeanalizowała wyniki badań, opisując doświadczenia matek chorych na raka oraz ich percepcję macierzyństwa.

Podczas trwania kolejnej, jedenastej sesji prelegenci koncentrowali się na analizach związanych z pandemią COVID-19 w doświadczeniach matek. Pierwsze wystąpienie wygłosiła pani prof. KUL dr hab. Dorota Kornas-Biela, koncentrując się na psychologicznych aspektach wczesnego macierzyństwa w świetle pandemii COVID-19. W dalszej kolejności pani prof. UG dr hab. Maria Kaźmierczak, pani mgr Agata Ruźniak-Lubocka oraz pani mgr Paulina Anikiej-Wiczenbach wygłosiły referat 
pt. „Macierzyństwo w czasie pandemii COVID-19. Jakościowa analiza doświadczeń matek w Polsce”. Kolejne wystąpienie: „Mama na zdalnym. Łączenie pracy z rodzicielstwem w czasach pandemii. Na podstawie doświadczeń pracujących zdalnie matek dzieci w wieku szkolnym” zaprezentowane zostało przez panią dr Alicję Zbierzchowską. Prelegentka ukazała wyniki badań, które odnosiły się do doświadczeń matek łączących pracę zdalną z wychowywaniem dzieci w wieku szkolnym. Ostatnie wystąpienie w tej sesji wygłosiła pani mgr Nina Myalska, która opowiedziała o roku na stacji kosmicznej z Aspi, czyli o doświadczeniach pandemicznych matek dzieci z zespołem Aspergera. Prelegentka przedstawiła wpływ sytuacji pandemicznej na funkcjonowanie rodzin z dziećmi z Zespołem Aspergera.

Dwunastą sesję (plakatową) otworzyło wystąpienie pani prof. dr hab. Hanny Liberskiej pt. „Satysfakcja z życia młodych kobiet i mężczyzn pełniących role rodzicielskie a siła doświadczanego stresu i radzenie sobie z trudnościami”. Pani profesor ukazała współzależności pomiędzy doświadczaniem stresu, sposobami radzenia sobie z nim a ich wpływem na poziom satysfakcji z życia młodych ludzi. W dalszej kolejności głos zabrały pani prof. UAM dr hab. Aleksandra Parobkiewicz-Jasielska oraz pani dr Renata Marsymiuk, które zaprezentowały referat: „„Córkomatki« - komercjalizacja macierzyństwa oczami nastolatek - doniesienia z badań". Prelegentki zajęły się ważkim poznawczo tematem oscylującym wokół świadomości konsumenckiej oraz jej wpływu na relację matka - córka, która w dalszej kolejności warunkuje wybory konsumenckie. Kolejne prelegentki przedstawiły referat pt. „Mediacyjna rola tłumienia (subiektywnej kontroli) depresji w relacji między samooceną młodych matek a ich satysfakcją z życia”. Pani dr Dorota Suwalska-Barancewicz oraz pani dr Alicja Malina zaprezentowały wyniki badań, podczas których poszukiwały odpowiedzi na pytanie, czy tłumienie lub też kontrola depresji może być związana z poziomem występującej samooceny u młodych matek. Ostatnie wystąpienie w sesji plakatowej obejmowało temat: „Znaczenia samooceny dla lęku porodowego u młodych kobiet”. Pani dr Natalia Pilarska oraz pani dr Ewelina Kamasz zaprezentowały wyniki badań własnych, które odnosiły się do związku samooceny badanych kobiet i nasilenia lęku porodowego oraz wszystkich obszarów związanych z postrzeganiem zjawiska porodu.

Kolejna, trzynasta sesja, oscylowała wokół tematów związanych z rodzicielstwem w obliczu trudności (cz. 2). Pierwszy z referatów, który został wygłoszony przez panią dr Dorotę Szczygieł, poruszał temat poszukiwania mechanizmów związku pomiędzy perfekcjonizmem rodzicielskim a wypaleniem rodzicielskim. Drugie wystąpienie pt. „Doświadczenia i problemy matek z uszkodzeniami słuchu w kontaktach z instytucjami publicznymi - analiza badań własnych" zaprezentowała pani mgr Beata Iwanicka, przedstawiając rezultaty analiz pozwalających na wyłonienie oraz charakterystykę wybranych trudności obecnych w codzienności matek z uszkodzeniami słuchu. Trzecie wystąpienie pt. „Rodzice dziecka zagrożonego niepełnosprawnością - (nie)obecność wsparcia” wygłosiła pani mgr Beata Bawolska-Piszczatowska, podkreślając, iż pandemia znacząco wpływa na doświadczenia rodziców. Wystąpieniem zamykającym sesję trzynastą był referat dotyczący macierzyństwa wobec dziecka z mózgowym porażeniem dziecięcym. Pani mgr Agnieszka Bójko zaprezentowała wyniki badań dotyczące wpływu pandemii na postawy oraz doświadczenia macierzyństwa w dobie narodowej kwarantanny.

Czternasta sesja obejmowała tematy związane z pandemią COVID-19 w doświadczeniach rodziców. Pierwszy z referatów odnosił się do tematu kontroli rodzicielskiej i karmienia dzieci w czasie pandemii. Pani dr Julia Wojciechowska wskazała, ale także poddała analizie strategie oddziaływania rodziców, które podejmowane są w celu kształtowania umiejętności samoregulacji żywieniowej dzieci. Pani dr Elżbieta Kornacka-Skwara przedstawiła obraz rodziców w okresie pandemii w rysunkach dziewcząt z rodzin uzależnionych. Prelegentka przedstawiła wyniki badań dziewcząt, których 
jeden z rodziców, a konkretnie ojciec, jest osobą uzależnioną od alkoholu. Wyniki badań pozwoliły na ukazanie sposobu percepcji obrazu ojca w okresie dorastania. Doświadczenie ojcostwa w dobie pandemii to tematyka wystąpienia zamykającego sesję związaną z pandemią COVID-19 w doświadczeniach rodziców. Pan mgr Andrei Ahapau przeanalizował sposoby postrzegania ojcostwa w trakcie trwania pandemii. Analiza zebranych materiałów ukazała, iż w opinii badanych ojców pandemia w znaczącym stopniu wpłynęła na sposoby wypełniania roli rodzica.

Sesja studencka stała się sesją zamykająca całość konferencji. Pierwsze wystąpienie obejmowało aspekty bycia rodzicem po przejściach - doświadczenia przemocy rówieśniczej a postawy rodzicielskie. Mateusz Biniaś zaprezentował wyniki badań dotyczące związku pomiędzy doświadczeniami nadużyć rówieśniczych w dzieciństwie a przejawianymi postawami wychowawczymi w życiu dorosłym. W dalszej kolejności głos został oddany Natalii Gałązce, która wygłosiła referat pt. „Wpływ zaburzeń afektywnych na funkcjonowanie w roli rodzica”. Następnie głos zabrała Katarzyna Gapska, która omówiła kwestie rodzicielstwa i władzy rodzicielskiej w ujęciu prawnym oraz pedagogicznym. Wystąpienie zamykające sesję studencką obejmowało temat funkcjonowania rodziny adopcyjnej. Pani Julia Ostrowska przedstawiła zarówno problemy, jak i wyzwania, które wpisane są w procesy życia rodzinnego rodziny adopcyjnej.

Po zakończeniu obrad w ramach wszystkich sesji tematycznych prelegenci oraz zaproszeni goście uczestniczyli w podsumowaniu konferencji. Zamykając konferencję, pani profesor Lucyna Bakiera podziękowała wszystkim osobom zaangażowanym w jej organizację oraz wszystkim prelegentom za wkład i wysiłek włożony w przygotowanie każdego z wystąpień. Tym samym nastąpiło oficjalne zamknięcie dwóch dni obrad konferencyjnych.

Monika Kiszka

DOI: $10.14746 /$ psn.2021.2.14 